\title{
Flexibility of Sugar Chains Measured by Resonance Energy Transfer
}

\author{
共鳴エネルギー転移測定法での糖鎖の柔軟度の測定
}

\author{
Rice, K.G., Wu, P., Brand, L., and Lee, Y.C. Biochemistry (1991) 30, 6646-6655 \\ Wu, P., Rice, K.G., Brand, L., and Lee, Y.C. Proc. Natl. Acad. Sci.. USA (1991) 88, 9355-9359
}

Key Words: asialoglycoprotein receptor, energy transfer, flexibility of sugar chain, Ala-Asn-glycopeptide, molecular ruler

Since Haas(Haas et al., Proc. Natl. Acad. Sci. USA 72, 1807-1811, 1975) reported that the distance of oligopeptides having two fluorophores could be measured by resonance energy transfer, resonance energy transfer has been utilized effectively as a molecular ruler to measure distances $(20-50 \AA)$ in biopolymers. However, there have been no reports on studies using energy transfer on carbohydrates.

Although proton-NMR(NOE) technique has been used to measure conformation of carbohydrates and oligosaccharides in solutions, this technique requires one $\mathrm{mg}$ of sample and can measure a distance in the range of $1-5 \AA$.

Y.C. Lee's group has been carrying out studies on the mechanism of binding of asialoglycoprotein receptor to the natural and synthetic ligands and has obtained many elegant results. They have shown that clustering of terminal Gal residues is necessary for the tight binding of asialoglycoprotein receptor(Lee et al., J. Biol. Chem., 258, 199-202, 1983). They have also reported that triantennary glycopeptide binds to the receptor in unique geometry(Rice, K.G., and Lee, Y.C., J. Biol. Chem., 265, 18423-18428, 1990).

In these two papers, they have measured internal distance and flexibility of the glycopeptide by resonance energy transfer. They partially oxidized the triantennary glycopeptide from bovine fetuin with galactose oxidase, and the products were reacted with (2,4-dinitorophenyl)hydrazine. The resulting oxidized compounds were separated with reverse phase HPLC, and identified mono-, di- and tri-oxoglycopeptides with proton NMR. Three kinds of mono-oxoglycopeptides were treated with dansy ethylenediamine by reductive amination, and GP- $\underline{6}-$ Dan, GP- $\underline{6}$-Dan, and GP- $\underline{8}$-Dan, where the underlined number indicates to which Gal residue the dansyl group is linked as shown in Fig. 1. Naphthyl-2-acetyl group was introduced into
Haasらの研究(Haas et al., Proc. Natl. Acad. Sci. USA 72, 1807$1811,1975)$ によって溶液中の $2 つ の$ 蛍光発色団を持つオリゴペ プチドの距離がエネルギー転移測定法によって測定されて以 来、この方法は生体高分子の $20-50 \AA \AA$ の距離の測定に分子の物差 しとして有効に使用されてきた。しかし、糖鎖を対象とした研 究は全くなされていなかった。

従来、糖鎖とオリゴ糖の溶液中のコンフォメーションの測 定には1H-NMR(NOE)が広く用いられてきたが、この'H-NMRは $1 \mathrm{mg}$ 程度のサンプルを必要とし、1-5 凡の距離を測定するのに適 している。

Leeらの研究グループでは哺乳動物の肝臓に存在するアシ アロ糖タンパクレセプターと合成と天然のリガンドの結合の機 構について研究を長年に渡って行い、多くの見事な業績をあげ てきた。彼らはリガンドの末端のGal残基の集合の配列がアシア ロ糖タンパクレセプターとの強固な結合に必要である事を示し た[Lee et al., J. Biol. Chem. (1983) 258, 199-202]。又、彼らはtriantennary糖ペプチドがユニークな幾何学的配列でアシアロ糖タン パクレセプターと結合する事を報告した[Rice, K.G., and Lee, Y.C., J. Biol. Chem. (1990) 265, 18423-18428]。

本論文では彼らは初めてエネルギー転移測定法を用いて糖 ペプチドの非還元末端間の距離と柔軟度の測定をした。即ち、 彼らは牛のフェツインの triantennary糖ペプチドをガラクトース オキシダーゼで部分的に酸化し、(2,4-dinitorophenyl)hydrazine と 反応させ、逆相液体クロマトグラフィーで分離し、再生後、モ 人、ジ、トリオキソ糖ペプチドを ${ }^{1} \mathrm{H}-\mathrm{NMR}$ で同定した。そして それぞれのモノオキシ糖ペプチドをダンシルエチレンジアミン

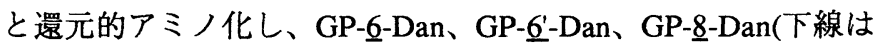
ダンシル化されたGal残基を示す。図1参照。)を得た。これらを ナフチル酷酸とサクシノイミドエステルでアラニン残基のN末 端と反応させ、GP- $\underline{6}$-DanNap、GP- $\underline{6}$-DanNap、GP- $\underline{8}$-DanNap、

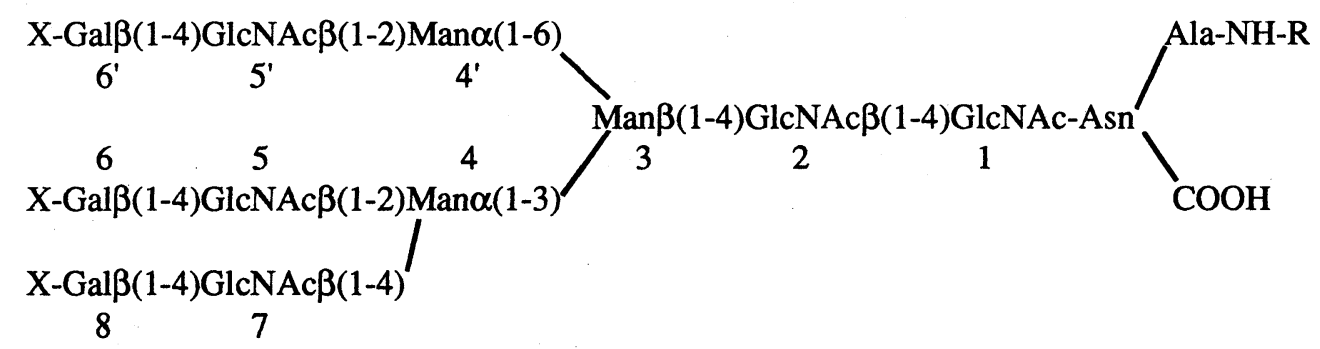

$\mathrm{X}=$ dansylethylenediamine, $\mathrm{R}=$ naphthyl-2-acetyl

Fig. 1. Structure of triantennary glycopeptide fluorescence energy-transfer probes 
each dansylated monooxoglycopeptide via $\mathrm{N}$-terminus of alanine, and four kinds of probe, Gp-6-DanNap, Gp-6'-DanNap, Gp-8-DanNap, and Gp-Nap were obtained. They collaborated with Brand in the same Department of The Johns Hopkins University to measure flexibility of the glycopeptide by resonance energy transfer. In this method the dansyl group was an energy acceptor and the naphytyl-2-acetyl group was an energy donor. The examples of the results were shown in Fig. 2. Fig. 2A indicates that the distance between $\mathrm{A}$ and $\mathrm{D}$ is 1.7 , and 1.0 , and 2.0 $\mathrm{nm}$ respectively. Fig. $2 \mathrm{~B}$ shows that there are two kinds of distance, 1.0 and $2.0 \mathrm{~nm}$ respectively, and Fig. $2 \mathrm{C}$ shows that the distances are 1.2 and $1.8 \mathrm{~nm}$, respectively.

Please see the papers for details. They have concluded that the distance between each Gal residue and alanine, that is, the distance of the donor attached to Gal residue and the acceptor at alanine is 18,17 and $22 \AA$. The Gal residue of 8 is the most rigid lacking flexibility, and the distribution of the distance between $\mathrm{Gal}$ and alanine is one kind. On the other hand, the distribution in the case of Gal of 6 and 6' is two kinds, and the Gal residue of 6 and 6 are flexible. These results agree closely with the data shown by Lee's group. Several research groups have already reported that, and these data support the earlier conclusions.

Thus, resonance energy transfer is able to measure the flexibility of sugar chains, and this method will be one of the useful techniques in understanding the role of carbohydrates in the field of glycobiology.

\section{Reported by Kichitaro Kawaguchi}

BTG Inc./Second Department of Biochemistry, Teikyo University School of Medicine

Ibaraki-ken 300-15/Tokyo 193, Japan
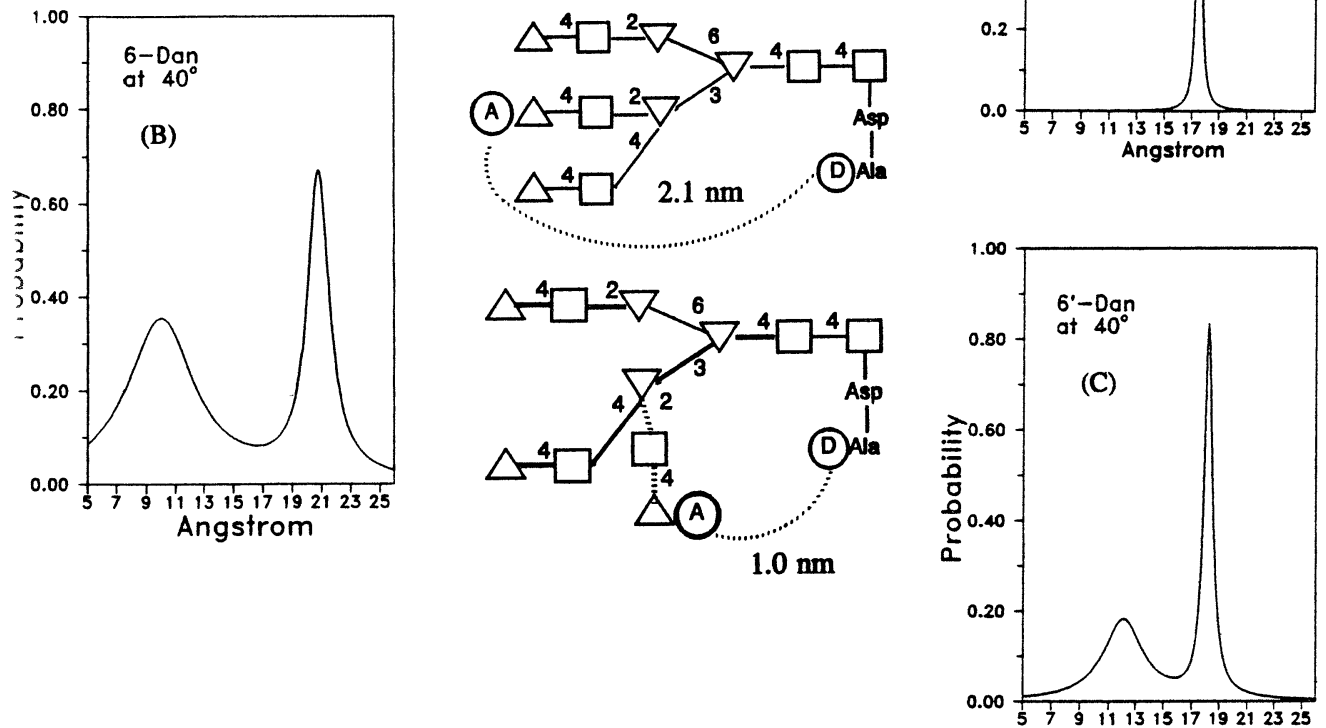

GP-Napの4種類のプローブを調製した。彼らはジョンズ・ホプ キンス大学生物学科のBrand と共同でこれらのプローブを用いて 共鳴エネルギー転移で糖鎖の柔軟度を測定した。この方法を簡 単に説明すると、ダンシルグループはエネルギー受容体、ナフ チル-2-酢酸グループはエネルギー供与体として用いられた。実 際の測定の結果の例を図2に示した。図2AではA-D間の距離が $1.7 \mathrm{~nm} ゙$ あり、図2BではA-D間の距離が2種類あり、それぞれ $1.0 \mathrm{~nm} 、 2.0 \mathrm{~nm} ゙$ あ、図2CではA-D間の距離が同様に2種類あ り、それぞれ $1.2 \mathrm{~nm} 、 1.8 \mathrm{~nm}$ である事を示している。

その詳細は原報を参照して頂きたいが、結論として彼らは Gal残基と Ala残基の距離が $18 、 17 、 22 \AA ̊(8 、 6 、 69 \mathrm{Gal}$ 残基に結 合した供与体と受容体の距離)である事を明かにした。そして8 のGal残基が最もリジッドで、Gal残基と $\mathrm{Ala}$ 残基の距離の分布が 1 種類であり、柔軟度に欠けるが、6、6のGal残基と $\mathrm{Ala}$ 残基の 距離の分布はそれぞれ2種類あり、柔軟度がある事を証明した。 この結果はLeeグループの今迄のデータと符合する。既に幾つか の研究グループの研究によってN-結合糖鎖のMan $\alpha(1-6)$ Man結合 には柔軟度があることが報告されており、Leeらの結果はこれを 支持している。

このように共鳴エネルギー転移法は分子の物差しとして糖 鎖の柔軟度の測定ができ、この方法は今後糖鎖生物学の糖鎖の 役割を理解する上で有効な手段の一つとなるだろう。

BTG／帝京大学・医学部・第二生化学教室

川口 吉太郎
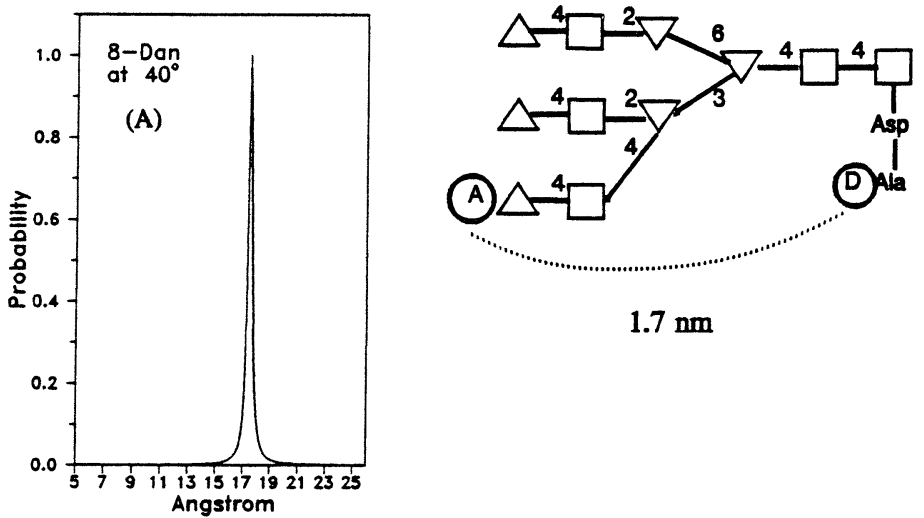

$1.7 \mathrm{~nm}$
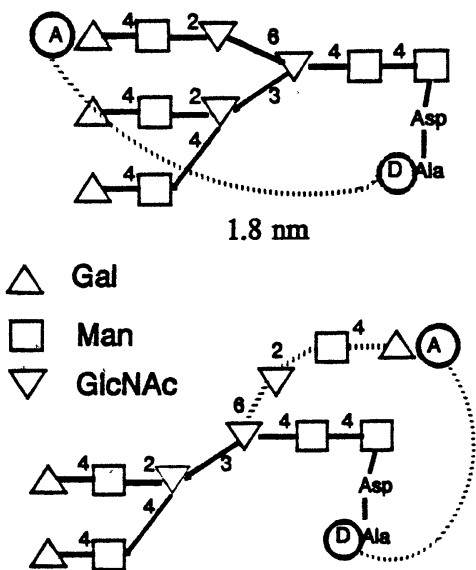

$1.2 \mathrm{~nm}$

Fig. 2. Donor/acceptor population distributions. Lorentzian fit of the donor decay curves and illustrated results for GP- 8 -DanNap(A), GP-6-DanNap(B), and GP-6́-DanNap(C). These data were kindly supplied by Dr. Y.C. Lee. 